УДК 339.187

DOI: https://doi.org/10.26642/jen-2020-1(91)-21-26

Ю.О. Головчук, к.е.н., доц. Вінницький торговельно-економічний інститут КНТЕУ

Л.В. Дибчук, к.і.н., Доц.

Віннищький кооперативний інститут

\title{
Формування та особливості ефективної рекламної кампанії
}

Реклама часто є відображенням суспільства, постійно слідує за останніми тенденціями. Маркетологи використовують ї як інструмент для емоційних реакиій. Бренди поєднують потужні повідомлення, засновані на добре вивченій ідеї, та ефективні методи доставки, які впливають на їхню аудиторію.

Однак із постійно мінливою парадигмою споживання ЗМI, контроль над тим, як надходить повідомлення, перейшов від маркетологів до споживачів. Проблема реклами переросла творчі повідомлення та вражаючі візуальні зображення. Це пошук оптимального способу доставки повідомлення, яке надійде до споживача у потрібний час і місиі, за допомогою використання нового асортименту інструментів.

Реклама - це інвестиція у бізнес і вона подібна до інших інвестицій, які призначені для покращення та розширення бізнесу. Результат иієї інвестиції залежить від плану та думок, які передують зобов'язанням та витратам. Розробивши ефективну рекламу, компанія планує збільшити ймовірність позитивної віддачі від свойх інвестицій у рекламу, незалежно від кількості грошей, яку витрачає.

Отже, стратегії успішної рекламної бізнес-кампанії є важливим фактором для кожної компанії та бізнесу. Незалежно від того, чи споживач дивиться телебачення, гортає журнал або слухає радіо, які кожного разу пропонують придбати товар чи отримати послугу.

На сьогодні розробиі ефективної рекламної кампанї приділяється недостатньо уваги. Підприємства обмежені у фінансових ресурсах та не підходять комплексно до оцінки ефективності рекламної кампанії, тому це призводить до скорочення бюджетів підприємств. Попри численні дискусії щуодо того, чи є реклама ефективною, і чи є люди, які купують відповідні товари, реальність така, що багато компаній витрачає мільярди на рекламу з надією, щзо це буде збільшувати їх прибуток. Хороша реклама має силу спонукати людей помічати і купувати товар, тому шляхи створення ефективної рекламної кампанії стали набагато складнішими.

У роботі визначено, щь реклама є найважливішим засобом для просування товару підприємства на ринок. Встановлено два основні методи проведення дослідження ринку: первинні та вторинні дослідження. Досліджено найпоширеніші методи просування маркетингу, а саме: реклама, просування реклами, рекламні подарунки, конкурси, листівки. Проведено аналіз маркетингових стратегій просування продукиії підприємства.

Створення та реалізація рекламної кампанії - непросте завдання. Тисячі рекламних агентств по всьому світі переповнені людьми, які провели своє життя за вивченням майстерності рекламної діяльності.

Ключові слова: рекламна кампанія; реклама; розробка стратегї; методи просування.

Постановка проблеми. Ефективність реклами - проблема надзвичайно серйозна. На цю тему вже давно тривають суперечки. Безумовно, необхідно дуже виважено підходити до планування рекламної кампанії та до медіапланування, оскільки при виборі рекламних носіїв і місць розміщення реклами необхідно враховувати такі речі, як охоплення аудиторії тощо. Однак навіть бездоганно спланована i проведена рекламна кампанія, з продуманим вибором рекламних носіїв, медіапланом, розробленим 3 урахуванням максимального охоплення представників цільової аудиторії, може виявитися абсолютно неефективною.

Аналіз останніх досліджень та публікацій, на які спираються автори. Значний внесок у дослідження ефективної рекламної кампанії зробили такі вчені, як Ф.Котлер, Д.Траут, С.Годін, Г.Фельсер, Р.Акша, Н.Іншакова, С.Ромат, Р.Каптюхін, М.Понявін, С.Ілляшенко, С.Ковальчук, В.Стадник та інші.

Метою статті $є$ удосконалення розробки ефективної рекламної кампанії.

Викладення основного матеріалу. Реклама - один з багатьох інструментів маркетингу, що забезпечує важливу функцію - комунікацію. Навіть не враховуючи важливість маркетингу як основи бізнесу, підприємства використовують рекламу як просто інформування покупців про ціни на продукцію та умови поставки, так і повний іiі спектр, що включає всі можливі методи і засоби [1].

(C) Ю.О. Головчук, Л.В. Дибчук, 2020 
Реклама перетворилася на найважливіший маркетинговий інструмент, який допомагає виходу продукції на ринок. Друковані та електронні засоби масової інформації стають актуальною невід'ємною частиною життя, реклама взяла на себе вирішальну роль в успіху нових продуктів. Існує жорстка конкуренція за здобуття левової частки на ринку, тож кращі рекламні стратегії дають більші шанси на успіх.

Більшість практиків вважає, що ефект від проведення маркетингової діяльності проявляється у збільшенні продажів або прибутку підприємства. Тому, на їх думку, ефективність маркетингу варто розраховувати за допомогою економіко-математичних методів як співвідношення маркетингових витрат до результатів маркетингової діяльності - обсягів продажу або прибутку [2].

Успішна рекламна кампанія повідомляє клієнту, що продукт - це не просто товар, а це продукт, який рухається, щоб стати брендом в очах споживачів. Джингли стають популярними серед мас, яких надихає мелодія, слоган або інші інструменти успішних рекламних кампаній.

Маркетингові стратегії регулюють успіх продуктів та рекламних носіїв маркетингового плану. У прагненні отримати максимальний прибуток і забезпечити ефективність реклами, маркетингові компанії та рекламні агенції зосереджуються на дослідженні ринку. Підприємства, які ігнорують та не проводять результативні маркетингові дослідження, ризикують отримати величезні збитки від неефективної рекламної кампанії. Знання про цільову аудиторію та розуміння іiї потреб допомагають маркетологам більш цілеспрямовано та ефективно досягти своєї мети. Дослідження ринку також допомагає входженню продукту відповідно до потреб ринку. Для розвитку на конкурентному ринку, для покращення власних конкурентних переваг, потрібне ефективне дослідження ринку. Тому, аналізуючи різні параметри, підприємства можуть знайти кращі рішення та варіанти. Дослідження ринку - це процес систематичного збору даних про конкретний цільовий ринок, конкурентів, споживачів, тенденції на ринку тощо. Метою дослідження ринку є досягнення поглибленого розуміння конкретного продукту на ринку. Зростаюча конкуренція змушує все більше підприємств проводити маркетингові дослідження. Підприємства можуть самостійно проводити дослідження ринку, призначивши групу дослідників. А в іншому випадку вони можуть це зробити через консультацію 3 маркетинговими агентствами. Маркетингове дослідження є життєво важливим для організацій, які шукають можливості виходу на ринок, для підприємств, які створили інноваційний товар і хочуть оцінити попит на нього, а також компаній, які планують представити свою продукцію на ринку. Проводячи дослідження ринку, важливо визначити його цілі. Дослідження ринку можна проводити різними способами [3].

Більшість науковців виділяе два основні методи проведення дослідження ринку: первинні та вторинні, вибір яких залежить від цілей дослідження.

При первинних дослідженнях дані збираються безпосередньо з джерела. Наприклад, якщо мета дослідження полягає в тому, щоб визначити попит на конкретний товар, збір інформації відбувається безпосередньо у споживача, під час розмови з ним. Первинне дослідження містить збір важливих даних за допомогою інтерв'ю, опитування або фокус-груп - це високовартісний та трудомісткий процес, однак він підходить для збору конкретних даних. Первинні дослідження можна додатково класифікувати на якісний та кількісний тип.

Кількісне первинне дослідження - це тип первинних досліджень, який враховує збір числових даних за допомогою опитувань. Найчастіше використовується кількісна методика «опитування ринку», а отримана числова або кількісна інформація статистично аналізується. Такі опитування містять анкети із закритим кінцем запитання, у якому респонденту потрібно відповісти, поставивши галочку поряд 3 одним із запропонованих варіантів. У більшості випадків респоденти погоджуються співпрацювати, коли опитування не займає багато часу та нетрудомісткі. Наприклад, банк може сформувати анкету, мета якої є з'ясування, думки кліснта про його послуги. Отримані дані аналізуються статистично і робиться висновок. Особливістю кількісного дослідження $є$ те, що всім респондентам пропонують однакову анкету, такий самий набір запитань. Кількісні опитування можуть проводитись як віч-на-віч (опитування людей на вулиці), електронною поштою, телефоном або поштою (самозаповнення та надсилання анкети адресату).

Якісне первинне дослідження - це тип досліджень, який включає в себе збір даних через відкриті запитання за допомогою інтерв'ю або сесії фокус-груп. На запитання такого типу досліджень не можна відповісти «так» чи «ні». Вони включають поглиблені інтерв'ю, під час яких підготовлений інтерв'юер опитує одного або декількох респондентів. Інтерв’юер може проводити інтерв'ю «один на один», 3 двома, трьома або навіть групами по чотири-п'ять респондентів. Такі відкриті інтерв'ю дозволяють досліднику отримувати дані, позитивно-негативні відгуки, тенденції та емоції. На відміну від кількісного, якісний тип не складається з фіксованого набору питань - це інтерв'ю є експромтом, хоча інтерв'юер може мати готові основні запитання. Респондент має свободу самовираження, що допомагає інтерв'юеру краще зрозуміти ситуацію.

Фокусні групи - це один із методів проведення якісних досліджень, які полягають в опитувані шести-восьми респондентів досвідченими фахівцями (модераторами досліджень). Роль професіонала 
полягає в тому, щоб поставити загальні, а також конкретні запитання групі респондентів, заохочуючи обговорення, а після цього оформити необхідну інформацію. Оскільки фокус-групи вимагають досвідчених професіоналів, це - дорога технологія дослідження.

В основі здатності підприємства створювати щось нове лежить його сприйнятливість до нових знань, до абсорбції цих знань із зовнішнього середовища і перетворення їх у нові, унікальні, яких немає у конкурентів. Згодом ці знання матеріалізуються у продукти і послуги, що формуватимуть нові споживчі потреби [4].

У вторинних дослідженнях проводиться аналіз інформації, яку збирають для іншого призначення. Вторинні дослідження проводяться методом збирання даних з таких джерел, як державні публікації, бібліотеки, Інтернет, журнали, торгові палати тощо. Потрібна інформація може бути у формі демографічних чи статистичних даних, набору статей або деяких досліджень. Підприємства можуть аналізувати свої цільові ринки, оцінювати конкурентів, соціальні, політичні та економічні фактори. Дані для другорядних досліджень можуть бути отримані з різних джерел, таких як:

- торгово-промислові палати: кожний обласний центр має торговельну палату, яка володіє інформацією про місцевий бізнес та місцеву громаду;

- центри ділової інформації: підприємства малого бізнесу можуть використовувати такі центри, які мають велику колекцію книг, відео, публікацій та інших важливих ресурсів і матеріалів;

- торгові асоціації, що надають інформацію про лідерів галузі, стандарти, яких вони дотримуються, останні тенденції, конкурентів тощо;

- відділи маркетингу місцевих навчальних закладів: підприємства можуть отримати доступ до спеціальних досліджень, проектів, підготовлених студентами;

- оптовики та виробники, інформація про яких стосується позитивних та негативних відгуків клієнтів, скарг, витрат тощо;

- галузеві журнали та газети - чудове джерело важливої інформації. Події, останні новини про політику, економічні показники тощо. Це корисно фірмам для розуміння ринку та його тенденцій;

- дослідження щодо товарів чи послуг, цін, брошур, маркетингових методів, що допомагають підприємствам зрозуміти, як розвивати свій бізнес.

Крім перерахованих ресурсів, підприємства можуть отримувати дані з бібліотек, різних книг та видань, статистичних збірників найважливіших галузей економіки, банків, страхових компаній, компаній 3 нерухомості тощо. Недоліком вторинних досліджень $є$ те, що дані можуть бути неоновлені і не відповідати потребам дослідження. Оскільки аналіз інформації зроблений з іншою метою, то може бути неточним. Наприклад, фірма з виготовлення шкіряних сумок може дізнатися, скільки людей купує їхні сумки, використовуючи вторинні дослідження. Однак вона не може визначити кількість людей, готових заплатити за їхній дизайн шкіряної сумки.

Для підприємств, які планують вихід нового товару чи послуги, проведення маркетингових досліджень дає можливість зрозуміти ставлення та потреби клієнтів. Це також мінімізує ризик понести збитки в бізнесі. Дослідження ринку, проведене або первинним, або вторинним методом, є життєво важливим для будь-якого бізнесу, його цілей та розвитку.

В умовах підприємницької мережі реалізація ринкового потенціалу підприємств здійснюється за допомогою переформатування частини зовнішнього ринку на внутрішньомережевий на основі застосування інструментів конкуренції, унікальної організації та синергетичних можливостей [5].

Важливою частиною ефективної рекламної кампанії є застосування методу стратегії маркетингового міксу на етапі планування та впровадження в потрібний час у певний спосіб. Маркетинговий мікс передбачає розгляд таких елементів маркетингу, як товар, ціна, просування та місце. Також він стосується логістичних та транспортних витрат товарів. Тому маркетологи та рекламні агенції використовують змінні маркетингового поєднання для успіху продукту.

Переважно є дві стратегії просування: стратегія тиску і стратегія поштовху. Відповідно до стратегії тиску, маркетологи дають щедрі знижки та вигоди для покупців, тому продажі можуть бути різко збільшені. Метод надання знижок часто найбільш успішний серед стратегій для більшості країн. У стратегії поштовху основний акцент робиться на зменшенні витрат на рекламу. Стратегія притягування мінімізує використання різних каналів і основна увага приділяється рекламі товару. Ïї мета - створити потенційний ринок для продукції фірми.

Розглянемо найпоширеніші методи просування маркетингу.

Реклама - це дорогий метод маркетингу, де продукти виготовляються для того, щоб охопити велику кількість споживачів. Наприклад, за допомогою телебачення, радіо та преси рекламодавці орієнтуються на аудиторію і намагаються вплинути на споживачів.

Кожна бізнес-імперія зміцнювала свій імідж та фінансову стабільність завдяки наполегливій праці та задовольняючи якість і рівень попиту клієнта. Однак кожній невеликій організації потрібно вивести своє ім'я на ринок, привернувши увагу покупця. Рекламні ідеї відіграють важливу роль у визначенні ринку 
для малого бізнесу. Кожен бізнес використовує інноваційну ідею просування, щоб вразити свою цільову аудиторію [6].

Просування реклами - це інструмент, який використовується для того, щоб донести споживачеві ідею про покупку продукту. Ідеї реклами використовуються з метою підштовхнути споживача до покупки товару, викликати інтерес до нього та створити попит на товар. Існує чимало способів реклами які можуть бути використані в бізнесі. Сьогодні найефективнішим способом реклами $\epsilon$ рекламні подарунки.

Споживач задоволений під час отримання подарунка, а отже, рекламні подарунки - найбільш ефективний спосіб створення фактора доброзичливості серед споживачів (тобто потенційних покупців певного товару). Рекламні подарунки привертають увагу споживача до бренда, назви компанії та фірмового гасла. Споживач за допомогою цих рекламних подарунків знайомиться 3 конкретним логотипом та ім'ям бренда.

Рекламні подарунки - це інтерактивні рекламні ідеї, які надаються у вигляді призів потенційним клієнтам. Деякі призи призначені для певної цілі, а деякі - просто для розваги. Побутове канцелярське приладдя, друковані стаціонарні з назвою компанії календарі, ковпачки, футболки, рушники, торгові ваучери на конкретний бренд - це декілька прикладів рекламних подарунків. Також подарункова продукція, в розумінні іiі призначення, давно стала ефективним елементом налагодження міжособистісних та колективних зв’язків і потужним інструментом маркетингових комунікацій.

Конкурси - одна 3 найкращих рекламних ідей для компаній. Прізвище переможця буде голосно звучати разом з назвою торгової марки компанії.

Листівки - це брошури, які містять коротку інформацію про компанію та товар. Процес розповсюдження флаєрів реалізується через продавців газет або через найм на неповний робочий день. Розповсюдження листівки в газетах - це найкращий спосіб забезпечити іiі доставку потенційному споживачеві. Купони зі знижкою або безкоштовні купони працюють на користь невеликих роздрібних торговців.

Одним із найдавніших способів просування є прямий маркетинг - продаж продукції за допомогою прямої взаємодії між продавцем і покупцем. Вважається, що це найскладніша форма маркетингу, оскільки вимагає навичок переконання та відмінних комунікативних навичок [7].

Ми часто вимушені домовлятися, оскільки працюємо на посадах, де необхідно вести переговори. Більшість людей помилково вважає, що навички ведення переговорів є тільки у продавців. Але уявімо ситуацію, що хтось планує продати будинок. Без переговорів, він може в кінцевому підсумку отримати ціну, яка набагато нижча від реальної вартості будинку. Подумайте про втрати, яких, можливо, доведеться зазнати, лише через невміння вести переговори. Отже, навички ведення переговорів можуть бути дуже корисними, навіть якщо людина не займається продажем. Для людей у торгових компаніях відмінні навички ведення переговорів є обов'язковими. Продаж компанії залежить від «переговорів про продаж» та ціни, яку вона отримає за товар.

Однією з ефективних, популярних і найбільш бажаних форм рекламних методів є проведення конкурсів для споживачів. Це найпривабливіша маркетингова стратегія і геніальний спосіб просування продукції.

У прагненні залучити більше клієнтів, компанії роздають купони та брошури про товари. Клієнти отримують або основну інформацію про нещодавно запущені товари, або купони зі знижкою на придбання певних речей. Купони створюють ефективний маркетинговий план для малих бізнес-одиниць.

Ідея вільно розповсюджувати продукти незвична для будь-якої компанії. Водночас маркетингові фірми досягли суттєвого просування за допомогою безкоштовних зразків товару. Для того щоб поширювати свою продукцію, компанія має розробити стратегію, аби ідея безкоштовних зразків не привела до зростання витрат підприємства.

Оцінюючи різні методи просування в маркетингу, слід усвідомити, що ці стратегії не є формулами або рецептами успішного запуску й високого рівня продажу товару. Без сумніву, ці стратегії ефективні, але існують різні чинники ринків, які можуть вплинути на перспективи продажу підприємства [8].

Отже, сучасна маркетингова концепція, або холістичний маркетинг, - це такий підхід до управління підприємством, який дозволяє збалансувати потреби підприємства, клієнтів, споживачів та суспільства [9].

Існують різні види рекламних носіїв, що пов'язано з їх ефективністю. Завдяки великій кількості рекламоносіїв споживачі дізнаються про різні продукти на ринку. Газета та телевізійна реклама - одні 3 найдавніших використовуваних методів реклами. 3 появою в Інтернеті сучасних методів реклами, таких як вебсайти соціальних мереж, реклама в пошукових системах та Інтернет-партнерський маркетинг, саме вони завоювали найбільшу популярність.

Реклама в спонсорованих посиланнях основних пошукових систем стала однією 3 найефективніших Інтернет-реклам. Доступ до Інтернету став таким величезним, що кожна людина в будь-якому куточку світу може переглянути рекламу вашого продукту. Більше того, якщо у компанії є вебсайт, вона може 
використовувати оптимізацію пошукових систем, у яких цей вебсайт потрапить до топ-10 результатів пошукових систем.

Сучасна реклама в Інтернеті суттєво відрізняється своїм широким спектром форм і способами подачі інформації. Фахівці у сфері просування Інтернет-торгівлі враховують новітні комп'ютерні технології і нестандартні способи подачі матеріалів. Їх використання призводить до зміни якості і природи самої реклами [10].

Потрапляння до перших кількох рейтингів допомагає отримати ширшу аудиторію, що, в свою чергу, може призвести до більшої кількості продажів. Інші форми реклами містять рекламу з оплатою за клік та рекламу по електронній пошті, які також можна використовувати.

Реклама на телебаченні надає образ бренда. Найголовніше - це переконлива пропозиція, якою б аудиторія зацікавилася. За цей короткий проміжок часу потрібно надати повну контактну інформацію: адресу вашого вебсайту, номер телефону.

Висновки та перспективи подальших досліджень. Реклама має чітку мету, а способи іï досягнення і ступінь ефективності досліджено та показано в цій статті. Проведено аналіз, який показує, що проектування рекламної кампанії - це сукупність взаємопов'язаних, скоординованих дій, що розробляються для досягнення стратегічних цілей і рішення проблем підприємства, і $є$ результатом загального рекламного плану для різних, але пов'язаних один з одним рекламних звернень, розміщених у різних ЗМІ протягом певного періоду часу.

\section{Список використаної літератури:}

1. Основні правила і етапи створення рекламного звернення / Елітаріум. - 2018 [Електронний ресурс]. Режим доступу : http://www.elitarium.ru/sozdanie-reklamy-obyavlenie-tovar-cel-torgovaya-marka-nazvaniereklamnoe-obrashchenie-tekst-soobshchenie-argument-kompoziciya/.

2. Лукан O.М. Аналіз ефективності та напрямки оптимізації витрат маркетингової діяльності на підприємствах хлібопекарської галузі / О.М. Лукан // Вісник ЖДТУ. - 2017. - № 2 (80). - С. 16-20 [Електронний ресурс]. Режим доступу : http://ven.ztu.edu.ua/article/download/106329/104695.

3. Influence of transformational economic processes on marketing management by an international diversified conglomerate enterprise / A.Tanasiichuk, O.Hromova, A.Abdullaieva and other // European journal of sustainable development. - Italy : European center sustainable development. - Vol. 8. - № 3 [Electronic recourse]. - Access mode : https://ecsdev.org/ojs/index.php/ejsd/article/view/898.

4. 9 кроків до створення ефективної рекламної кампанії / Towave. - 2018 [Електронний ресурс]. - Режим доступу : http://www.towave.ru/pub/9-shagov-k-sozdaniyu-effektivnoi-reklamnoi-kampanii.html.

5. Каптюхін Р.В. Використання методик креативності при створенні реклами / Р.B. Каптюхін // Економіка $\mathrm{i}$ сучасний менеджмент: теорія і практика. - 2013. - № 32. - С. 8-13.

6. Понявін М.Б. Нові нестандартні методи використання QR-кодів в маркетинговій політиці сучасних компаній / М.Б. Понявін // Економіка і сучасний менеджмент: теорія і практика. - 2014. - № 34. - С. 82-86.

7. Kovalchuk $S$. Formation of a system approach to the optimization of marketing management at an enterprise / S.Kovalchuk, D.Kobets, L.Dybchuk // Восточно-Европейский журнал передовых технологий. - 2016. № 3 (4). - $\quad$ C. 4-12 [Електронний http://nbuv.gov.ua/UJRN/Vejpte_2016_3\%284\%29_2.

8. Стадник В.В. Маркетинг взаємодії в розвитку інноваційного та ринкового потенціалу підприємства / В.В. Стадник, П.Г. Іжевський, Ю.О. Головчук // Ефективна економіка. - 2018. - № 2 [Електронний pecypc]. - Режим доступу : http://ojs.dsau.dp.ua/index.php/efektyvna-ekonomika/article/view/1061.

9. Пчелянська Г.О. Маркетингові підходи до формування ринку агропродовольчих товарів / Г.О. Пчелянська // Бізнес Інформ. - 2019. - № 2. - С. 202-208 [Електронний ресурс]. - Режим доступу : https://doi.org/10.32983/2222-4459-2019-2-202-208.

10. Дибчук Л.В. Інноваційні технології подання інформації в Інтернет-рекламі / Л.В. Дибчук, А.О. Васількова // Економіка і суспільство. - 2018. - Вип. 19. - 389 с. [Електронний ресурс]. - Режим доступу : https://doi.org/10.32782/2524-0072/2018-19-58.

\section{References:}

1. «Osnovni pravyla i etapy stvorennja reklamnogo zvernennja» (2018), Elitarium, [Online], available at: http://www.elitarium.ru/sozdanie-reklamy-obyavlenie-tovar-cel-torgovaya-marka-nazvanie-reklamnoeobrashchenie-tekst-soobshchenie-argument-kompoziciya/

2. Lukan, O.M. (2017), «Analiz efektyvnosti ta naprjamky optymizacii' vytrat marketyngovoi' dijal'nosti na pidpryjemstvah hlibopekars'koi' galuzi», Visnyk ZhDTU, No. 2 (80), pp. 16-20, [Online], available at: http://ven.ztu.edu.ua/article/download/106329/104695

3. Tanasiichuk, A., Hromova, O., Abdullaieva, A., Holovchuk, Y. and Sokoliuk, K., «Influence of transformational economic processes on marketing management by an international diversified conglomerate enterprise», European journal of sustainable development, European center sustainable development, Italy, Vol. 8, No. 3, [Online], available at: https://ecsdev.org/ojs/index.php/ejsd/article/view/898

4. «9 krokiv do stvorennja efektyvnoi' reklamnoi' kampanii'» (2018), Towave, [Online], available at: http://www.towave.ru/pub/9-shagov-k-sozdaniyu-effektivnoi-reklamnoi-kampanii.html 
5. Kaptjuhin, R.V. (2013), «Vykorystannja metodyk kreatyvnosti pry stvorenni reklamy», Ekonomika $i$ suchasnyj menedzhment: teorija i praktyka, No. 32, pp. 8-13.

6. Ponjavin, M.B. (2014), «Novi nestandartni metody vykorystannja QR-kodiv v marketyngovij polityci suchasnyh kompanij», Ekonomika i suchasnyj menedzhment: teorija i praktyka, No. 34, pp. 82-86.

7. Kovalchuk, S., Kobets, D. and Dybchuk, L. (2016), «Formation of a system approach to the optimization of marketing management at an enterprise», Vostochno-Evropejskij zhurnal peredovyh tehnologij, No. 3 (4), pp. 4-12, [Online], available at: http://nbuv.gov.ua/UJRN/Vejpte_2016_3\%284\%29_2

8. Stadnyk, V.V., Izhevs'kyj, P.G. and Golovchuk, Ju.O. (2018), «Marketyng vzajemodii' v rozvytku innovacijnogo ta rynkovogo potencialu pidpryjemstva», Efektyvna ekonomika, No. 2, [Online], available at: http://ojs.dsau.dp.ua/index.php/efektyvna-ekonomika/article/view/1061

9. Pcheljans'ka, G.O. (2019), «Marketyngovi pidhody do formuvannja rynku agroprodovol'chyh tovariv», Biznes Inform, No. 2, pp. 202-208, [Online], available at: https://doi.org/10.32983/2222-4459-2019-2-202-208

10. Dybchuk, L.V. and Vasil'kova, A.O. (2018), «Innovacijni tehnologii' podannja informacii' v Internet-reklami», Ekonomika i suspil'stvo, Issue 19, 389 p., [Online], available at: https://doi.org/10.32782/2524-0072/2018-19-58

Головчук Юлія Олександрівна - кандидат економічних наук, доцент кафедри маркетингу та реклами Вінницького торговельно-економічного інституту КНТЕУ.

Наукові інтереси:

- маркетинг взаємодії в управлінні інноваційною діяльністю підприємства.

http://orcid.org/ (0000-0002-4516-109X).

E-mail: holovchuk312@ua.fm

Дибчук Людмила Василівна - кандидат історичних наук, доцент, завідувач кафедри маркетингу та підприємництва Вінницького кооперативного інституту.

Наукові інтереси:

- використання інструментів системи маркетингових комунікацій на підприємствах.

http://orcid.org/ (0000-0001-6609-1951).

E-mail: important@email.ua 